\title{
A rapid spectrophotometric method for quantitative determination of lactulose in heated milk and milk products
}

\author{
AK Adhikari, D Sahai, ON Mathur
}

National Dairy Research Institute, Division of Dairy Chemistry, Karnal (Haryana), India 132001

(Received 20 August 1990; accepted 20 February 1991)

\begin{abstract}
Summary - The reddish-brown colour produced on heating protein-free filtrate of heated milks containing less than $1.0 \%$ lactose and free of ions in $6.4 \mathrm{~N}$ sulphuric acid was used for quantitative determination of lactulose. The absorptivity of the coloured solution of lactulose at $330 \mathrm{~nm}$ was 14fold more than that obtained from 62.5 -fold more concentration of lactose and other aldoses. By following the optimum conditions established in this method, a minimum of $10 \mathrm{mg} / 100 \mathrm{ml}$ concentration of lactulose can be determined in high heated unsweetened milk and milk products. The method was found to be very useful and sufficiently sensitive under dairy industry conditions where the ion removed step can be omitted if raw milk filtrate is taken for blank preparation.
\end{abstract}

lactulose / carbohydrate / heat treatment / dried milk / UHT milk

Résumé - Méthode rapide de dosage par spectrophotométrie du lactulose dans le lait et les produits laitiers chauffés. La méthode de dosage du lactulose proposée est basée sur sa propriété à produire une coloration rouge brune au cours du chauffage $\left(100{ }^{\circ} \mathrm{C}-20 \mathrm{~min}\right)$ en milieu sulfurique $(6,4 \mathrm{~N})$. L'absorption de la solution de lactulose colorée à $330 \mathrm{~nm}$ est 14 fois supérieure à celle d'une solution de lactose et d'autres aldoses dont la concentration est 62,5 fois supérieure. Cette méthode permet, en suivant les conditions optimales établies, de déterminer une concentration minimale de $10 \mathrm{mg} / 100 \mathrm{ml}$ de lactulose dans des laits et produits laitiers non sucrés ayant subi un fort traitement thermique. Elle est en outre très utile et suffisamment sensible à l'échelle industrielle où l'étape de désionisation peut être supprimée si le filtrat de lait cru est pris comme blanc.

lactulose / hydrate de carbone / traitement thermique / poudre de lait / lait UHT 


\section{INTRODUCTION}

Lactulose (4-O-B-D-galactopyranosyl-Dfructo-furanose) is formed in heated milks by the alkaline isomerization of lactose catalysed by the free amino group of casein (Richards and Chandrasekhara, 1960; Adachi and Patton, 1961). Lactulose occurs in 2 forms: as lactulose in free solution, and as N-deoxylactulosyl-L-lysine which is covalently bound to the amino group of the milk proteins (Henry et al, 1948).

The formation of lactulose in heated milks is dependent on time and temperature of heating and is also significantly affected by the $\mathrm{pH}$ of the environment (Adachi, 1959; Martinez-Castro and Olano, 1980). The lactose concentration in raw milk plays an important role in the formation of lactulose (Andrews, 1989).

Several methods have been used for the determination and quantification of lactulose in milk and milk products. The major problem with quantification of lactulose arises from the fact that the concentration of lactose is far in excess of that in milk and milk products. Most of the methods therefore include preliminary separation of carbohydrate mixtures or application of a specific aldose reaction to remove the lactose and thereafter quantification of lactulose either by a general carbohydrate method or by TLC, GLC or HPLC methods. Such methods are not only cumbersome and expensive, but also timeconsuming when a large number of samples have to be analysed.

The spectrophotometric method of Adachi (1965) utilizes a lengthy procedure of oxidation of aldoses to aldonic acid by hypoiodate, whereas the anthrone method of Zagrodzki et al (1968) is reported to give slightly higher values as anthrone reacts with 5-hydroxymethylfurfural. The methylamine method of Nikerson et al (1976) is not very useful in milk where the lactose content is much higher than that of lactulose. The spectrophotometric method of Parrish et al (1980) is time-consuming and requires separate determination of all carbohydrates.

This paper describes a simple and rapid spectrophotometric method which does not require separation of lactulose from lactose or other aldoses and can be conveniently applied for quantification of lactulose in unsweetened milk and milk products.

\section{MATERIALS AND METHODS}

The principle of this method is based on the fact that ketoses are decomposed far more easily than aldoses by the action of mineral acids which produces an intense red or violet colouration, while the colour appears relatively slowly and is less intense when mineral acids act upon aldoses (Stanĕk et al, 1963). As heated milks contain no ketose other than lactulose (Gordon et al, 1956), the principle applied in this method is specific and consistent.

\section{Materials}

AR grade lactulose (98.0\%) was obtained from Sigma Chemical Co, USA. $6.4 \mathrm{~N} \mathrm{H}_{2} \mathrm{SO}_{4}$ (AR grade) and $40.0 \%$ TCA (AR grade) solution were freshly prepared before use. Amberlite IR120 and Amberlite IR-458 (Sigma Chemical) were used as cation and anion exchanger respectively. $\mathrm{HCl} 3 \mathrm{~N}$ and $\mathrm{NaOH} 2 \mathrm{~N}$ (AR grade) were used for washing the column.

\section{Standard methods used for comparative study}

Lactulose was separated by TLC method of Martinez-Castro and Olano (1981) followed by quantification by the method of Adachi (1965) and cysteine-hydrochloride-carbazole colorimet- 
ric method of Fujita and Iwatake (1931). The results obtained were compared with the $\mathrm{H}_{2} \mathrm{SO}_{4}$ method. Total carbohydrate content in the milk filtrate was determined by the phenol-sulphuric acid method of Brich and Mwangelwa (1974).

\section{Milk samples}

UHT milk samples were obtained from a commercial milk plant (indirect type) which had been processed at $140^{\circ} \mathrm{C} / 3 \mathrm{~s}$. Sterilized $\left(120^{\circ} \mathrm{C} / 15\right.$ $\mathrm{min}$ ) and boiled milk (10 $\mathrm{min}$ ) samples were prepared in the laboratory from fresh cow's milk. Skim milk powders (roller-and spray-dried) were collected from the experimental dairy at the $\mathrm{Na}$ tional Dairy Research Institute, Karnal, India.

\section{Method}

Ten $\mathrm{ml}$ of warmed milk $\left(37^{\circ} \mathrm{C}\right)$ was treated with $40 \%$ TCA solution and kept for $10 \mathrm{~min}$ to precipitate out the total proteins, and the final volume was made up to $100 \mathrm{ml}$ (dilution coefficient $10^{-1}$ ) with the same TCA solution. The whole content was filtered using Whatman No 42 filter paper.

\section{Removal of interfering ions}

To remove the interfering ions (cations $\mathrm{Ca}^{2+}$, $\mathrm{Mg}^{2+}, \mathrm{Na}^{+}, \mathrm{K}+$ and anions $\mathrm{Cit}^{3-}, \mathrm{HPO}_{4}^{2+}, \mathrm{HCO}_{3}^{-}$, $\mathrm{SO}_{4}^{2-}$ and $\mathrm{RCOO}^{-}$and their complexes; Holt et al, 1981), the filtrate was passed through a cation exchange column then an anion exchange column in free base according to the procedure of Adachi (1965). The cation exchange column of Amberlite IR-120 in sodium form and the anion exchange column of Amberlite IR-458 were filled to $10 \mathrm{~cm}$ height in a $45-\mathrm{cm}$ high $18-\mathrm{mm}$ diameter column with glass wool and a flow control device. The former was treated with $100 \mathrm{ml}$ of $3 \mathrm{~N} \mathrm{HCl}$ and then washed with distilled water until the effluent showed a negative chloride test. The latter was treated with $100 \mathrm{ml}$ of $2 \mathrm{~N}$ $\mathrm{NaOH}$ and then rinsed with water until the effluent showed a negative base test with phenolphthalein indicator. The total milk filtrate was then allowed to pass successively through the 2 columns at the rate of $4-5 \mathrm{ml}$ per min, followed by washing with $100-110 \mathrm{ml}$ of distilled water.
The volume of the effluent was adjusted to 100 $\mathrm{ml}$ by removing excess water under vacuum at $65-70^{\circ} \mathrm{C}$.

\section{Development of colour}

Five $\mathrm{ml}$ of the above effluent was taken into a Pyrex $15 \times 1.5 \mathrm{~cm}$-test tube fitted with a glass stopper treated with $5.0 \mathrm{ml}$ of $6.4 \mathrm{~N} \mathrm{H}_{2} \mathrm{SO}_{4}$ and placed into a constantly boiling water bath $\left(100 \pm 0.5^{\circ} \mathrm{C}\right)$ for $20 \mathrm{~min}$. The tube was cooled immediately to $37 \pm 2{ }^{\circ} \mathrm{C}$ and absorbance was measured within $30 \mathrm{~min}$ at $330 \mathrm{~nm}$ by a spectrophotometer (Spectronic 20D) against a blank prepared in a similar manner but with $5 \mathrm{ml}$ of $40 \%$ TCA solution in place of the heated milk filtrate. For dried unsweetened milk powders, $1.0 \mathrm{~g}$ of the sample was dissolved in $10 \mathrm{ml}$ of warm distilled water, diluted to $100 \mathrm{ml}$ with $40 \%$ TCA solution (dilution coefficient $10^{-2}$ ) and the above procedure was followed for quantification.

\section{Calibration curve}

The calibration curve for lactulose was prepared by taking standard lactulose solution (conc 0.2$1.2 \mathrm{mg} / 5 \mathrm{ml}$ ) and developing the colour in a similar manner as for the milk filtrate.

\section{RESULTS AND DISCUSSION}

The action of mineral acids on sugars led to a number of decomposition products, some of which were coloured (Staněk et al, 1963). Besides a certain amount of humus-type decomposition, both aldohexoses and ketohexoses yield HMF as the main intermediate, which on further decomposition with acid produces furfural, a colouring substance.

\section{Absorbance spectra $\left(\lambda_{\max }\right)$}

Absorbance spectra of standard lactulose solution (conc $2.92 \times 10^{-3} \mathrm{~mol} / \mathrm{l}$ ) was $\mathrm{ex}$ - 
amined in the range of $310-345 \mathrm{~nm}$ wavelength by a Spectronic 20 D spectrophotometer (fig 1). The absorbance maxima $\left(\lambda_{\max }\right)$ was slightly broad and noted at 330 $\mathrm{nm}$ of $0.616 \times 10^{2} \mathrm{~mol} / \mathrm{l}$ absorptivity.

\section{Effect of concentration of acid on colour development}

The effect of the strength of sulphuric acid on lactulose and other aldoses after heating $20 \mathrm{~min}$ in a constantly boiling water bath $\left(100 \pm 0.5^{\circ} \mathrm{C}\right)$ on colour development is depicted in figure 2. It was observed that up to an acid concentration of $6.4 \mathrm{~N}$, colour development for $1.0 \%$ lactose, glucose and galactose solution was significantly less (OD $\leq 0.01$ ), whereas $0.016 \%$ solution

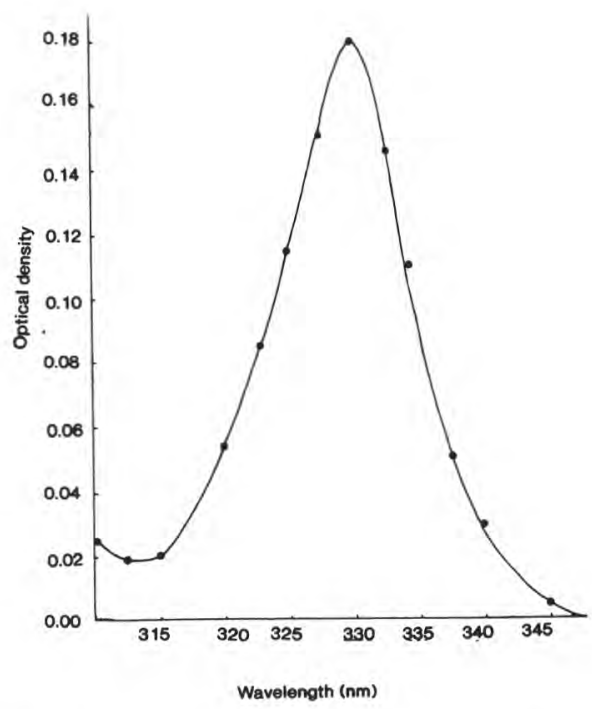

Fig 1. Absorption spectra of lactulose $(2.92 \times$ $\left.10^{-3} \mathrm{~mol} / \mathrm{l}\right)$ in $6.4 \mathrm{~N} \mathrm{H}_{2} \mathrm{SO}_{4}$ at different wavelengths.

Spectre d'absorption du lactulose $\left(2,92 \times 10^{-3}\right.$ mol/I) dans $\mathrm{H}_{2} \mathrm{SO}_{4} 6,4 \mathrm{~N}$, à différentes longueurs d'ondes. of lactulose gave nearly 14 times more colouration $(O D \approx 0.14)$. This reveals that the lactulose concentration of 62.5 times less than lactose and other aldoses produces 14 times more colouration with sufficient specificity.

\section{Effect of the length of heating time on colour development}

Rapid colour development was observed in the initial $20 \mathrm{~min}$ of heating of lactulose solution in $6.4 \mathrm{~N} \mathrm{H}_{2} \mathrm{SO}_{4}$, whereas the colour development for other aldoses was less ( $\leq 0.012$ OD) than that for lactulose for a similar extent of heat treatment (fig 3). Lactulose concentration of $0.02 \%$ produces 14 times more colouration $(O D \approx 0.178$ )

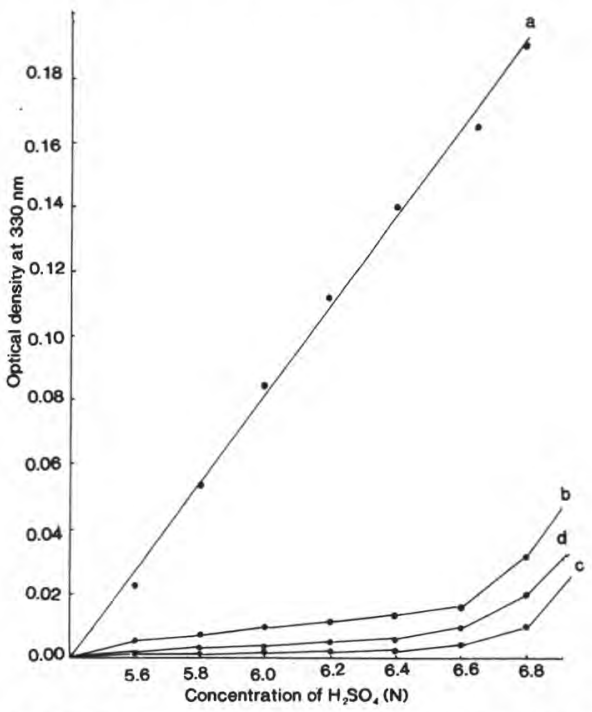

Fig 2. Effect of strength of $\mathrm{H}_{2} \mathrm{SO}_{4}$ on the colour development of lactulose and other aldoses. a: lactulose $(0.016 \%)$, b: lactose $(1.0 \%)$, c: glucose $(1.0 \%)$, d: galactose $(1.0 \%)$.

Effet de la concentration en $\mathrm{H}_{2} \mathrm{SO}_{4}$ sur l'intensité de la coloration produite par le lactulose et d'autres aldoses. a: lactulose $(0,016 \%)$, b: lactose $(1,0 \%)$, c: glucose $(1,0 \%)$, d: galactose $(1,0 \%)$. 


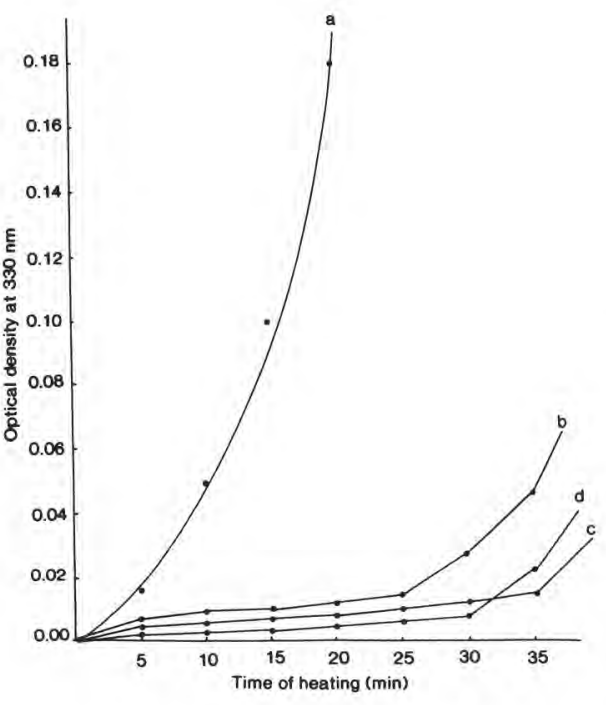

Fig 3. Effect of length of heating time on the colour development of lactulose and other aldoses. a: lactulose $(0.02 \%)$, b: lactose $(1.0 \%)$, c: glucose $(1.0 \%)$, d: galactose $(1.0 \%)$.

Effet de la durée du temps de chauffage sur l'intensité de la coloration produite par le lactulose et d'autres aldoses. a: lactulose (0,02\%), b: lactose $(1,0 \%)$, : glucose $(1,0 \%), d$ : galactose $(1,0 \%)$. than lactose and other aldoses at $1 \%$ concentration (OD $\leq 0.012$ ).

\section{Calibration curve for lactulose}

The plot of absorbance versus lactulose concentration $(0.2-1.2 \mathrm{mg} / 5 \mathrm{ml})$ was linear at $330 \mathrm{~nm}$ and obeyed the Beer-Lambert's law in this range. The concentration of the acid used and the time of heating were important determinant factors in the linearity of the curve. The higher the acid concentration and the time of heating, the greater the irregularities in the colour development observed. The regression equation developed for lactulose concentration ( $Y=\mathrm{mg}$ lactulose $/ 5 \mathrm{ml})$ and absorbance $(X=$ observed optical density) was calculated as:

$$
Y=28.50 X-0.10
$$

\section{Colour contribution of different aldoses in relation to lactulose equivalent}

Table I shows the relative colour development of lactose, glucose and galactose at

Table I. Colour contribution of different aldoses with respect to lactulose equivalent. Absorption à $330 \mathrm{~nm}$ du lactose du glucose et du galactose en fonction de leur concentration dans le filtrat.

\begin{tabular}{ccccc}
$\begin{array}{c}\text { Concentration (\%) } \\
\text { in the filtrate }\end{array}$ & \multicolumn{5}{c}{ Absorbance at $330 \mathrm{~nm}$} \\
\cline { 2 - 5 } & Lactose & $\begin{array}{c}\text { Interfering aldoses } \\
\text { Glucose }\end{array}$ & Galactose \\
\hline 0.50 & $0.000(0.00)^{*}$ & $0.000(0.00)$ & $0.000(0.00)$ \\
0.75 & $0.001(0.00)$ & $0.000(0.00)$ & $0.001(0.00)$ \\
1.00 & $0.004(0.18)$ & $0.002(0.00)$ & $0.003(0.00)$ \\
1.25 & $0.006(1.32)$ & $0.004(0.18)$ & $0.007(1.89)$ \\
1.50 & $0.018(8.16)$ & $0.009(3.03)$ & $0.016(7.02)$ \\
2.00 & $0.039(20.12)$ & $0.021(9.89)$ & $0.029(14.43)$ \\
\hline
\end{tabular}

\footnotetext{
* Figures in parentheses are $\mathrm{mg}$ equivalent lactulose per $100 \mathrm{ml}$ of filtrate.

Les chiffres entre parenthèses représentent des $\mathrm{mg}$ d'équivalent lactulose pour $100 \mathrm{ml}$ de filtrat.
} 
Table II. Effect of interfering aldoses on colour contribution at the same absorbance value. Poids relatif des différents aldoses pour une même valeur d'absorption.

\begin{tabular}{ccccc}
\hline \multirow{2}{*}{$\begin{array}{c}\text { Lactulose } \\
\text { (mg/100 ml filtrate) }\end{array}$} & $\begin{array}{c}\text { Absorbance } \\
\text { at } 330 \mathrm{~nm}\end{array}$ & \multicolumn{3}{c}{$\begin{array}{c}\text { Relative weight equivalent } \\
\text { of aldoses }(\mathrm{mg} / 100 \mathrm{ml})\end{array}$} \\
\cline { 3 - 5 } & & Lactose & Glucose & Galactose \\
\hline 10 & 0.02 & - & 2000 & 1800 \\
20 & 0.04 & 2000 & - & - \\
\hline
\end{tabular}

various concentration in relation to $\mathrm{mg}$ equivalent lactulose $/ 100 \mathrm{ml}$ of milk filtrate. It is evident from the table that $1.0 \%$ of lactose, galactose and glucose in milk filtrate contribute to the similar colour intensity of $\approx 0.18,0.00$ and $0.00 \mathrm{mg}$ of lactulose per $100 \mathrm{ml}$ in the respective milk filtrates. This clearly reveals that the intensity of colour contribution by aldoses is much less than that of the colour developed by lactulose even up to the $1.0 \%$ level. Table II represents the colour contribution of mg equivalent weight of lactulose in comparison to the $\mathrm{mg}$ equivalent of aldoses. It is evident from the results that $\approx 100,180$ and 200 times weight equivalent of lactose, galactose and glucose contribute a similar intensity of colouration to that of lactulose on following the optimum conditions prescribed in this method.

\section{Recovery studies}

Recovery studies were carried out by adding standard lactulose solution in heated milk and milk filtrate (in case of milk products). The results obtained are presented in table III. Approximately $97-101 \%$ recovery was observed, indicating high accuracy and reproducibility of the method developed.

\section{Effect of anion exchange resin on reducing sugars and raw milk filtrate}

The effect of anion exchange resin on reducing sugars is presented in table V. The result shows that on passing $1 \%$ lactose solution through the anion exchange resin there was a negligible increase in optical density at $330 \mathrm{~nm}$. The initial value of 0.010 increased to 0.013 on passing $1 \%$ lactose solution, while the initial value of 0.181 dropped slightly to 0.174 after passing the lactulose solution (conc $1 \mathrm{mg} / \mathrm{ml}$ ) through the anion exchange resin. At the same time when the raw milk filtrate was

Table III. Percentage of recovery of lactulose added to milk/milk filtrate.

Pourcentage de récupération du lactulose ajouté au laitffiltrat de lait.

\begin{tabular}{ccr}
\hline $\begin{array}{c}\text { Lactulose } \\
\text { added } \\
(\mathrm{mg} / 5 \mathrm{ml})\end{array}$ & $\begin{array}{c}\text { Lactulose } \\
\text { recovered } \\
(\mathrm{mg} / 5 \mathrm{ml})\end{array}$ & \% Recovered \\
\hline & & \\
1.0 & 0.98 & 97.79 \\
2.0 & 2.03 & 101.61 \\
3.0 & 3.00 & 100.04 \\
4.0 & 3.91 & 97.83 \\
\hline
\end{tabular}


Table IV. Lactulose content of heated milk and milk products - comparison of 3 different methods. Teneur en lactulose de laits et produits laitiers chauffés. Comparaison de 3 méthodes différentes.

\begin{tabular}{|c|c|c|c|c|c|c|}
\hline \multirow[t]{2}{*}{ Sample } & \multicolumn{6}{|c|}{ Lactulose $(\mathrm{mg} / 100 \mathrm{~g})$} \\
\hline & \multicolumn{2}{|c|}{ TLC method } & \multicolumn{2}{|c|}{ Cysteine - $\mathrm{HCl}$ - carbazole method } & \multicolumn{2}{|c|}{$\mathrm{H}_{2} \mathrm{SO}_{4}$ method } \\
\hline Boiled milk (10 min) & 84.24 & $(2.50)^{*}$ & 83.02 & $(2.75)$ & 85.40 & (2.55) \\
\hline Sterilized milk (15 min) & 166.77 & (2.22) & 162.60 & $(1.80)$ & 165.24 & (2.08) \\
\hline $\begin{array}{l}\text { UHT milk } \\
\text { (indirect type) }\end{array}$ & 58.60 & $(1.80)$ & 57.24 & $(1.35)$ & 56.04 & (1.56) \\
\hline SMP (roller-dried) & 478.28 & $(2.90)$ & 474.30 & $(2.75)$ & 479.80 & $(2.90)$ \\
\hline SMP (spray-dried) & 266.17 & (2.05) & 261.40 & $(2.25)$ & 268.34 & $(2.60)$ \\
\hline
\end{tabular}

* Figures in parentheses are standard deviations.

passed through the anion exchanger, the initial value of 0.153 dropped sharply to 0.028 due to removal of interfering ions and the subsequent colour development was very insignificant in contributing to lactulose value. This reveals that neither were the reducing sugars adsorbed nor was the lactose isomerized to lactulose while passing through the anion exchanger. Turton and Pacsu (1955) observed a negligible change in mutarotation and in the nature of the sugar solution (2\%) when passed through an anion exchange resin IRA-400$\mathrm{OH}$. However, they observed a rapid adsorption of D-glucose, D-fructose and Dmannose in the hydroxide form of resin; Dfructose was transformed to D-psicose, but no evidence was found of changes in reducing sugars like lactose or lactulose. Adachi (1965) reported no adsorption or

Table V. Effect of anion exchange resin on reducing sugars (ie lactose and lactulose) and raw milk filtrate.

Effet de la résine échangeuse d'anions sur l'absorption des sucres réducteurs (lactose et lactulose) et du filtrat de lait cru.

\begin{tabular}{|c|c|c|c|c|c|c|c|c|}
\hline \multicolumn{2}{|c|}{$\begin{array}{l}\text { Standard lactose } \\
\text { solution (1\%) }\end{array}$} & \multicolumn{2}{|c|}{ Raw milk filtrate } & \multicolumn{2}{|c|}{$\begin{array}{l}\text { Standard lactulose solution } \\
\text { (conc } 1 \mathrm{mg} / \mathrm{ml} \text { ) }\end{array}$} & \multicolumn{3}{|c|}{$n$ Added lactulose $(\mathrm{mg} / 5 \mathrm{ml})$} \\
\hline Untreated & Treated & Untreated & Treated & Untreated & Treated & Practical & Determined & $\%$ loss \\
\hline & & & & & & & & \\
\hline 0.005 & 0.010 & 0.155 & 0.030 & 0.185 & 0.178 & 5.0 & 4.86 & 2.80 \\
\hline 0.015 & 0.020 & 0.145 & 0.020 & 0.180 & 0.175 & & & \\
\hline Mean 0.010 & 0.013 & 0.153 & 0.028 & 0.181 & 0.174 & & & \\
\hline
\end{tabular}


isomerization of lactulose while passing it through strong cation and anion exchange resins for a long time to remove interfering ions and thereafter successfully determined lactulose content spectrophotometrically. Our findings also showed a negligible adsorption of lactulose and no isomerisation of lactose to lactulose while passing through the anion exchange resin. This might be due to the strong acidic environment present in resin provided by the milk filtrate containing $40 \%$ TCA solution.

\section{Omission of the ion exchange step: effect of changes in absorbance with raw milk filtrate and addition of lactulose solution}

To study the efficacy of the method by omitting the ion exchange step, raw milk filtrate replaced heated milk filtrate and the lactulose solution was added at an increasing concentration, (fig 4) with the

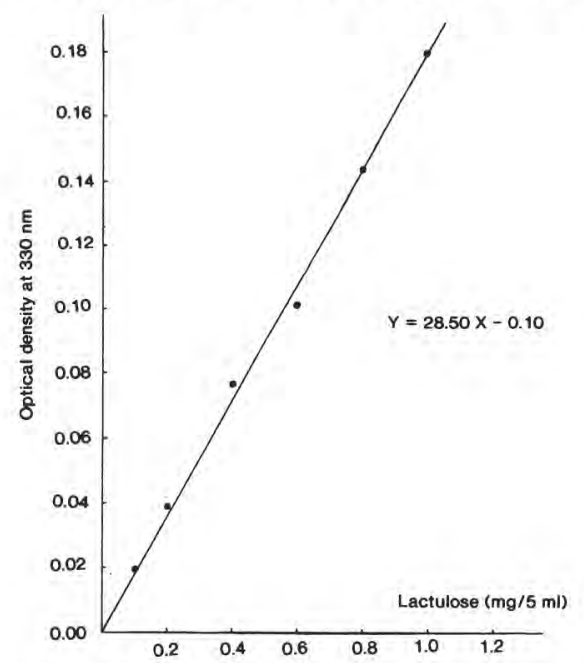

Fig 4. Calibration curve for lactulose (conc 1.16 $\times 10^{-4}$ to $\left.7.01 \times 10^{-4} \mathrm{~mol} / \mathrm{l}\right)$. Courbe de calibration pour le lactulose (conc $\left.1,16 \times 10^{-4}-7,01 \times 10^{-4} \mathrm{~mol} / \mathrm{l}\right)$. same quantity of raw milk filtrate to make up the total volume to $5 \mathrm{ml}$. Both the systems were treated in a similar manner for colour development as depicted in figures 5 and 6 . The linearity of both the slopes curves reveals that they obeyed the BeerLambert's law accurately in the given concentration range of lactulose and raw milk filtrate. This signifies the sensitivity and accuracy of the method, provided the raw milk filtrate is used in place of $40 \%$ TCA solution needed for the preparation of the blank.

\section{Efficacy in the determination of lactu- lose content by using raw milk filtrate as blank}

Table VI shows the values of lactulose concentration added and determined in raw milk filtrate when the same raw milk filtrate concentrations were used for blank preparation. The results reveal an accura-

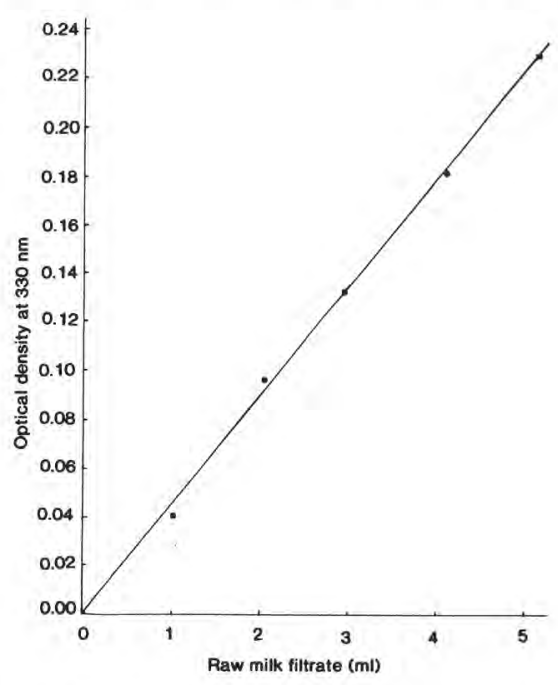

Fig 5. Absorbance of raw milk filtrate. Absorption de filtrat de lait cru. 


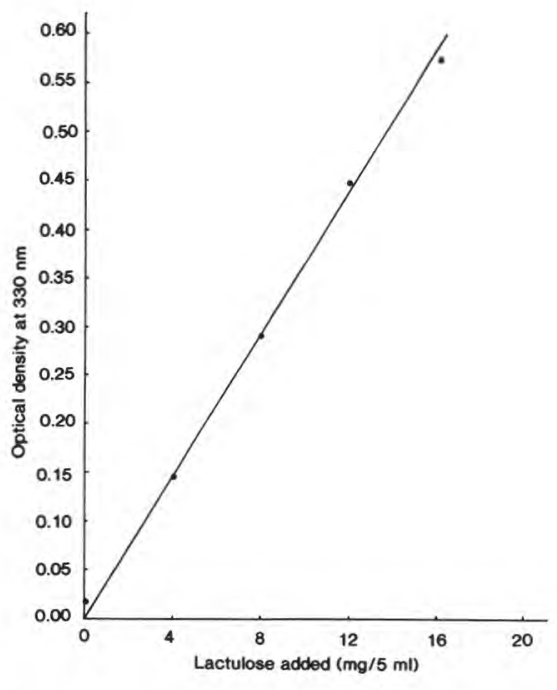

Fig 6. Absorbance of lactulose solution heated with raw milk filtrate.

Absorption de la solution de lactulose chauffée avec un filtrat de lait cru.

cy of $101.85 \%$ (mean value) in determining the lactulose concentration when raw milk filtrate was taken for blank preparation instead of $40 \%$ TCA solution. Slightly higher values may be attributed towards the effect of interfering ions, lactose and aldoses, which might have some influence on colour development in this context.

\section{Comparison with standard methods}

The method developed was compared with the procedure described by MartinezCastro and Olano (1981) and the cysteinehydrochloride-carbazole method of Fujita and Iwatake (1931). The results obtained (table IV) by the method developed were comparable, consistent and reproducible with sufficient accuracy (standard deviation of 2.9) as compared to the other 2 methods. The slightly higher values obtained for milk powders may be attributed to the higher pre-heating temperatures followed under Indian conditions.

\section{CONCLUSIONS}

The rapid and simple colorimetric method developed can successfully be performed within 2.5 to $3 \mathrm{~h}$ for routine quantitative determination of lactulose in unsweetened

Table VI. Lactulose content in raw milk filtrate, when raw milk filtrate was taken for blank preparation. Détermination des teneurs en lactulose ajouté dans un filtrat de lait cru (filtrat de lait cru pris comme blanc).

$\begin{array}{cccc}\text { Vol raw milk } & \begin{array}{c}\text { Vol lactulose } \\ \text { filtrate taken }(\mathrm{ml})\end{array} & \begin{array}{c}\text { Lactulose content }(\mathrm{mg} / 5 \mathrm{ml}) \\ \text { solution added }(\mathrm{ml})\end{array} & \begin{array}{c}\% \text { Accuracy } \\ (\mathrm{b} / \mathrm{a} \times 100)\end{array}\end{array}$

\begin{tabular}{rrrrr}
\hline 1 & 4 & 16 & 16.28 & 101.75 \\
2 & 3 & 12 & 12.44 & 103.66 \\
3 & 2 & 8 & 8.28 & 103.50 \\
4 & 1 & 4 & 3.94 & 98.50 \\
5 & 0 & 0 & 0.24 & - \\
& & & & Mean 101.85 \\
\hline
\end{tabular}


heated milk and milk products, and is also highly suitable under dairy industry conditions where raw milk is readily available. The ion exchange step can be omitted provided that the raw milk filtrate is taken for blank preparation and the colour developed in a similar manner to the sample. Hence a large number of samples can conveniently be analysed for their lactulose content to determine the severity of heat treatment with sufficient accuracy under dairy industry conditions.

\section{REFERENCES}

Adachi S (1959) The mechanism of the degradation of lactose in strongly heated milk. 15th Int Dairy Congr, London, 3, 1686-1691

Adachi S (1965) Spectrophotometric determination of lactulose with methylamine. Anal Chem 37, 896-898

Adachi S, Patton S (1961) Presence and significance of lactulose in milk products: a review. J Dairy Sci 44, 1375-1393

Andrews G (1989) Lactulose in heated milk. Bull Int Dairy Fed 238, 45-52

Brich GG, Mwangelwa OM (1974) Colorimetric determination of sugars in sweetened condensed milk products. J Sci Food Agric 25, 1355-1362

Fujita A, Iwatake D (1931) Biochem J 242, 43 (cited at the 15th Int Dairy Congr; Adachi S (1959) 3, 1686-1691)

Gordon HT, Thornburg W, Werum LN (1956) Rapid paper chromatography of carbohy- drates and related compounds. Anal Chem 28, 849-863

Henry KM, Kon SK, Lea CH, White JC (1948) Deterioration on storage of dried skim milk. J Dairy Res 15, 292-305

Holt C, Dalgleish DG, Jenness R (1981) Calculation of the ion equilibrium in milk diffusate and comparison with experiment. Anal Biochem 113, 154-163

Martinez-Castro I, Olano A (1980) Influence of thermal processing on carbohydrate composition of milk: formation of epilactose. Milchwissenschaft 35, 5-8

Martinez-Castro I, Olano A (1981) Ready detection of small amounts of lactulose in dairy products by thin-layer chromatography. Chromatographia 14, 621-622

Nickerson TA, Vujicic IF, Lin AY (1976) Colorimetric estimation of lactose and its hydrolytic products. J Dairy Sci 59, 386-390

Parrish FW, Hicks K, Doner L (1980) Analysis of lactulose preparations by spectrophotometric and high performance liquid chromatographic method. J Dairy Sci 63, 1809-1814

Richards EL, Chandrasekhara MR (1960) Chemical changes in dried skim milk during storage. J Dairy Res 27, 59-66

Staněk J, Černy M, Kocourek J, Pacák J (1963) The Monosaccharide. Academic Press, NY, 871-872

Turton CN, Pacsu E (1955) The effect of anion exchange resins on reducing sugars. $J \mathrm{Am}$ Chem Soc 77, 1059-1061

Zagrodzki S, Kulagowska A, Krol BW (1968) Qualitas Plantarum Mat Veg 18, 102-112 (cited in Andrews GR (1986) J Dairy Res Formation and occurrence of lactulose in heated milks. 53, 665-680) 